\title{
UJI INVITRO DAYA HAMBAT CENDAWAN ENDOFIT ASAL TUMBUHAN RAMBUSA (Passiflora foetida) SEBAGAI AGENS PENGENDALI HAYATI PENYAKIT LAYU FUSARIUM
}

\section{INVITRO TESTING OF ENDOPHYTIC FUNGI FROM RAMBUSA PLANT (Passiflora foetida) AS A BIOLOGICAL CONTROL AGENTS OF FUSARIUM WILT}

\author{
Nur Hidayat $^{1^{*}}$, Arini Rajab ${ }^{2}$, La Mudi ${ }^{1}$ \\ ${ }^{1}$ Program Studi Budidaya Tanaman Perkebunan, Politeknik Pertanian Negeri Samarinda, \\ ${ }^{2}$ Program Studi Pengelolaan Lingkungan, Politeknik Pertanian Negeri Samarinda, \\ Jl. Samratulangi, Samarinda 75131, Indonesia
}

\begin{abstract}
ABSTRAK
Cendawan endofit berperanan penting dalam pengendalian penyakit Fusarium sp. dan bersifat ramah lingkungan. Penelitian ini bertujuan untuk menguji cendawan endofit asal tumbuhan rambusa sebagai agens pengendali hayati penyakit Fusarium sp. Penelitian ini dilaksanakan di Laboratorium Ilmu Hama dan Penyakit Tumbuhan, Fakultas Pertanian Universitas Mulawarman, pada bulan April sampai Juni 2021. Penelitian disusun menggunakan rancangan acak lengkap yang terdiri dari 2 perlakuan yaitu cendawan endofit asal daun dan batang yang diulang sebanyak 5 kali sehingga diperoleh 10 unit percobaan. Data hasil pengamatan ditabulasi dan dianalisis secara deskriptif. Hasil penelitian menunjukkan bahwa isolat cendawan endofit yang diisolasi dari batang dan daun mampu menghambat cendawan Fusarium sp. Hal ini menunjukkan bahwa cendawan endofit yang diisolasi memberikan hasil yang sama dalam mengendalikan penyakit Fusarium sp. Hasil penelitian daya hambat tertinggi diperoleh pada isolat yang diisolasi dari daun yaitu sebesar 55,27\% pada pengujian hari ketujuh, bila dibandingkan dengan isolat cendawan endofit yang diisolasi dari batang yaitu sebesar 52,64\%. Berdasarkan hal kemampuan daya hambat tersebut maka isolat cendawan endofit yang diisolasi dari batang dan daun berpotensi digunakan sebagai agens pengendali hayati Fusarium sp.
\end{abstract}

Kata kunci: Agens biokontrol; Daya hambat; Fusarium sp.; Rhizopus sp.

\begin{abstract}
Endophytic fungi play an important role in controlling Fusarium sp. and environmentally friendly. The objective of this study was to assess the endophytic fungi from rambusa plant as a biological control agent for Fusarium sp. This research was carried out at the Laboratory of Pest and Plant Diseases, Faculty of Agriculture, Mulawarman University, from April to June 2021. The study was conducted using a completely randomized design consisting of 2 treatments, endophytic fungi from leaves and stems which were repeated 5 times so that 10 units were obtained. Observational data were tabulated and analyzed descriptively. The results showed that the endophytic fungi isolated from stems and leaves were able to inhibit the Fusarium sp. fungi. This indicated that the isolated endophytic fungi gave the same results in controlling Fusarium sp. The results showed that the highest inhibitory power was found in isolates isolated from leaves, which was $55.27 \%$ on the seventh day of testing, when compared with isolates of endophytic fungi isolated from stems, which was 52.64\%. Based on this inhibitory ability, endophytic fungi isolates isolated from stems and leaves have the potential to be used as biological control agents for Fusarium sp.
\end{abstract}

Keywords: Biocontrol agens; Inhibition.; Fusarium sp.; Rhizopus sp.

\footnotetext{
${ }^{*}$ Penulis Korespondensi.

E-mail: ayat_btp1@yahoo.co.id

Telp: +62-81346202525
} 


\section{Pendahuluan}

Peningkatan jumlah penduduk memicu kebutuhan akan tanaman pertanian juga semakin besar. Namun peningkatan jumlah penduduk tidak diikuti oleh peningkatan produksi tanaman pertanian. Salah satu penyebab rendahnya produksi tanaman pertanian yaitu serangan penyakit tanaman yang dapat menurunkan hasil tanaman (Saleh, 2004; Suwardani et al., 2014; Sudewi et al., 2020).

Salah satu penyakit yang dapat menyebabkan penurunan hasil tanaman pertanian yaitu penyakit layu yang disebabkan oleh patogen Fusarium sp. de Lamo and Takken (2020) melaporkan bahwa patogen Fusarium sp. dapat mengakibatkan penurunan kekebalan tanaman dan kematian sel. Hal ini tentunya akan berdampak besar terhadap penurunan hasil tanaman. Alternatif yang dapat digunakan untuk mengendalikan serangan penyakit ini yaitu dengan penggunaan pestisida sintesis yang dapat merusak lingkungan dan kesehatan manusia. Guna mengatasi hal tersebut, maka diperlukan teknologi yang lebih ramah lingkungan dan hasil produksinya lebih aman jika dikonsumsi dengan penggunaan agens hayati berupa cendawan endofit.

Cendawan endofit merupakan mikroorganisme yang berasiosisasi dengan jaringan tanaman yang mempunyai kemampuan sebagai agens pengendali hayati sekaligus memacu pertumbuhan tanaman (Suswanto et al., 2018; Rusae et al., 2018; Fitriani et al., 2019; Afriani et al., 2019). Tumangger et al. (2018) melaporkan bahwa cendawan endofit banyak ditemukan pada akar, batang dan daun tanaman dan mempunyai potensi yang cukup tinggi sebagai bioprotektan terhadap patogen Fusarium sp. (Tumangger et al., 2018).

Kemampuan daya hambat cendawan endofit dalam menghambat patogen disebabkan oleh kemampuan cendawan endofit yang menghasilkan senyawa kimia yang dapat menekan perkembangan patogen (Combès et al., 2012; Andrade-Linares \& Franken, 2013; Wei et al., 2019; Toghueo, 2020). Selain mekanisme tersebu, cendawan endofit juga mampu menekan patogen karena mekanisme persaingan ruang tumbuh dan nutrisi (Susanti et al., 2021).

Penggunaan agens biokontrol mampu menekan perkembangan penyakit layu fusarium pada bawang merah dengan periode laten penyakit terpanjang 21 hari dan menurunkan insidensi penyakit hingga 40\% (Fitriani et al.,
2019). Sudantha dan Abadi (2007) melaporkan bahwa cendawan endofit mampu bersifat antagonistik terhadap jamur $F$. oxysporum $\mathrm{f}$. sp. vanillae dengan menghasilkan antibiotik.

Cendawan endofit mampu menghambat konidia, Verticillium dahliae hingga mencapai 75-80\% dengan menghasilkan senyawa volatil (Wei et al., 2019). Lebih lanjut, Huda et al. (2019) melaporkan bahwa uji kemampuan metabolit volatil dan non-volatil isolat Neurospora sp. DG 27 menunjukkan persentase penghambatan tertinggi terhadap cendawan $C$. truncatum. Mekanisme penghambatan isolat Neurospora sp. DG 27 terjadi secara antibiosis sehingga terbentuk zona bening, sedangkan isolat DG 17 terjadi secara kompetisi dan isolat Syncephalastrum sp. AG 15 secara mikoparasit (Huda et al., 2019). Selain dapat berperan sebagai agens pengendali hayati, cendawan endfit juga dilaporkan mampu memacu pertumbuhan tanaman (Suswanto et al., 2018)

Berdasarkan potensi agens hayati tersebut, maka perlu dioptimalkan pemanfaatan agens hayati dari alam. Oleh karena itu, diperlukan isolasi dan pemanfaatan agens hayati tersebut mengedalikan penyakit tanaman. Penelitian ini bertujuan untuk menguji cendawan endofit asal tumbuhan rambusa sebagai agens pengendali hayati penyakit Fusarium sp.

\section{Metode Penelitian}

Penelitian dilaksanakan di Laboratorium Ilmu Hama dan Penyakit Tumbuhan, Fakultas Pertanian Universitas Mulawarman, pada bulan April sampai Juni 2021. Bahan yang digunakan pada penelitian ini Potato Dextrose Agar (PDA), $\mathrm{NaOCl}$, alkohol 70\%, spritus, tissue, label, plastik wrap dan aquades. Alat yang digunakan dalam penelitian ini yaitu, laminar air flow cabinet, hot plate, correr borer, autoclave, bunsen, cutter, shaker, speader, stirrer, mikroskop, kaca penutup, kaca objek, mistar, pipet tetes, kamera digital dan pingset.

Penelitian disusun menggunakan rancangan acak lengkap yang terdiri dari 2 perlakuan yaitu cendawan endofit asal daun dan batang, yang diulang sebanyak 5 kali sehingga diperoleh 10 unit percobaan.

Isolasi cendawan endofit. Cendawan endofit diisolasi dari tumbuhan rambusa, dengan mengambil batang dan daun. Masing-masing bagian tanaman ditimbang sebanyak $10 \mathrm{~g}$, kemudian dicuci bersih dengan air mengalir dan dikeringanginkan. Selanjutnya batang dan daun 
rambusa disterilisasi permukaannya dengan perendaman alkohol $70 \%$ selama 1 menit, dilanjutkan dengan perendaman dalam $\mathrm{NaOCl}$ 5\% selama 3 menit, kemudian dibilas dengan akuades steril sebanyak 3 kali. Selanjutnya jaringan tanaman digerus dengan menggunakan mortal steril terbentuk suspensi $100 \mathrm{~mL}$. Suspensi tumbuhan sebanyak $1 \mathrm{~mL}$ dicampurkan dalam 9 $\mathrm{mL}$ akuades steril dalam ependorf, kemudian dihomogenkan menggunakan vortex.

Pengenceran berseri dilakukan hingga tingkat pengenceran $10^{-5}$. Masing-masing suspensi pengenceran diambil sebanyak $0.5 \mathrm{~mL}$, dan disebar pada media PDA padat lalu diinkubasi selama 5 - 7 hari pada suhu ruang. Hifa cendawan endofit yang tumbuh selanjutnya dimurnikan untuk pengujian selanjutnya.

Isolasi Fusarium. Patogen Fusarium diisolasi pada tanaman lada yang terkena penyakit layu. Tanah pada tanaman lada terkena penyakit, diambil selanjunya dibawa ke laboratorium. Sebanyak $10 \mathrm{~g}$ tanah dicampur dengan aquades steril lalu di shaker selama 24 jam, selanjutnya dilakukan pengenceran berseri. Pada pengenceran $10^{-5}$ diambil $50 \mu \mathrm{L}$ lalu ditumbuhkan pada media PDA dengan cara disebar. Cendawan yang tumbuh selanjutnya diidentifikasi menggunakan mikroskop.

Uji antagonis agens hayati. Uji antagonis agens hayati dilakukan dengan uji ganda (dual cultutre) pada cawan petri yang berisi media PDA. Isolat cendawan ditumbuhkan yaitu cendawan ang berumur tujuh hari dengan dimeter $5 \mathrm{~mm}$ diletakkan pada media PDA berhadapan dengan patogennya. Jarak isolat cendawan dengan patogen yaitu $3 \mathrm{~cm}$ dan masing-masing berjarak $3 \mathrm{~cm}$ dari cawan petri (Gambar 1).

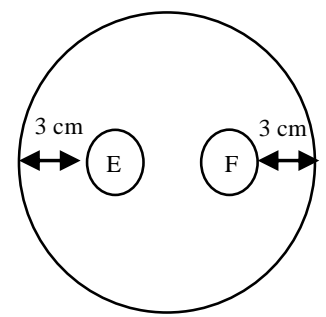

Gambar 1. Ilustrasi uji antagonis (dual culture method). Keterangan: $\mathrm{E}=$ endofit dan $\mathrm{F}=$ Fusarium

Pengamatan dilakukan terhadap daya hambat cedawan endofit dengan rumus:

$$
\mathrm{PI}=\frac{\mathrm{R} 1-\mathrm{R} 2}{\mathrm{R} 1} \times 100 \%
$$

Keterangan: $\mathrm{PI}=$ Persentase hambatan pertumbuhan miselium (\%), R1 = Diameter miselium Fusarium sp. pada cawan petri kontrol (cm), R2 = Diameter miselium Fusarium sp. pada cawan petri perlakuan $(\mathrm{cm})$. Kriteria persentase hambatan pertumbuhan (\%) yaitu persentase hambat tinggi: $70-100 \%$; persentase hambat sedang: 40-69\%; persentase hambat rendah: 0-39 \% (Amaria et al., 2013).

Data hasil penelitian ditabulasi dan dianalisis secara deskriptif.

\section{Hasil dan Pembahasan}

Hasil penelitian menunjukkan bahwa daya hambat cendawan endofit yang diisolasi dari daun mampu menghambat patogen Fusarium spp. yang ditunjukan dengan penimgkatan daya hambat terhadap patogen Fusarium setiap hari. Hal ini menunjukkan bahwa cendawan endofit ini mampu berperan sebagai agens pengendali hayati.

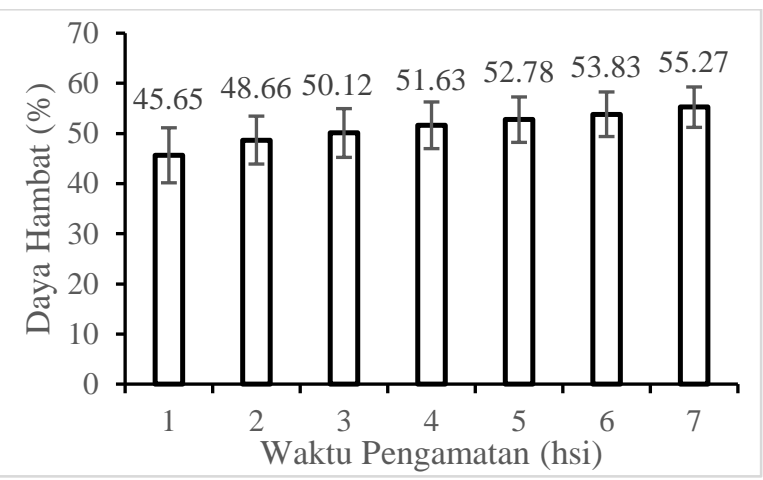

Gambar 2. Daya hambat cendawan endofit asal daun terhadap patogen Fusarium sp.

Gambar 1 menunjukkan bahwa uji daya hambat cendawan endofit asal daun tumbuhan rambusa mampu menekan laju pertumbuhan cendawan patogen Fusarium sp. yang diisolasi dari tanaman lada sakit. Gambar 1 menunjukkan bahwa terjadi peningkatan daya hambat patogen Fusarium sp. setiap harinya. Daya hambat cendawan endofit tergolong tergolong dalam kategori persentase daya hambat sedang yaitu mencapai $55,27 \%$.

Gambar 2 menunjukkan bahwa uji daya hambat cendawan endofit asal batang tumbuhan rambusa mampu menekan laju pertumbuhan cendawan patogen Fusarium sp. yang diisolasi dari tanaman lada sakit. Gambar 2 menunjukkan bahwa terjadi peningkatan daya hambat patogen Fusarium sp. setiap harinya. Daya hambat cendawan endofit tergolong dalam kategori 
persentase daya hambat sedang yaitu mencapai $52,64 \%$.

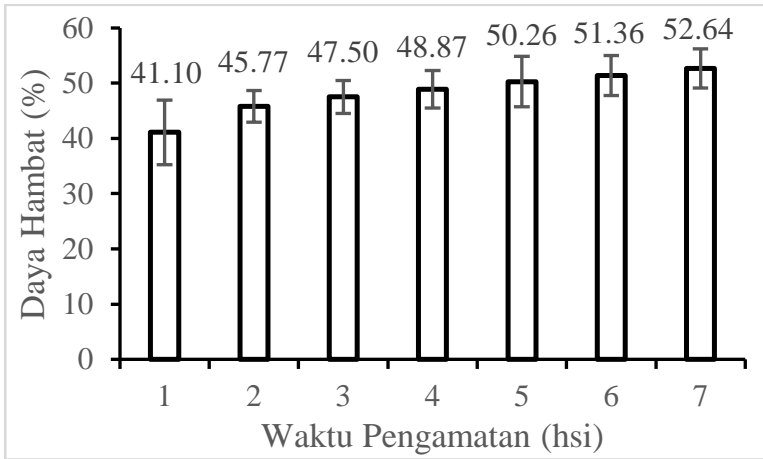

Gambar 2. Daya hambat cendawan endofit asal batang terhadap patogen Fusarium sp.

Kemampuan setiap cendawan endofit berbeda-beda dalam menekan perkembangan patogen (Sriwati et al., 2015; Wahyuni dan Noviani, 2019; Izzatinnisa et al., 2020; Basri et al., 2021). Perbedaan daya hambat ini sangat dipengaruhi oleh kemampuan cendawan endofit dalam menghasilkan senyawa metabolik yang dapat menekan perkembangan patogen (AndradeLinares \& Franken, 2013; Wei et al., 2019; Toghueo, 2020). Lebih lanjut dilaporkan bahwa mikroba endofit ini dapat memberikan strategi perlindungan dan kelangsungan hidup pada tanaman inangnya dengan produksi repertoar metabolit sekunder yang beragam secara kimiawi dan secara struktural menunjukkan serangkaian aktivitas biologis yang luar biasa termasuk antimikroba, antikanker, antivirus, antioksidan, antiparasit, imunosupresan, imunomodulator, antitrombotik, dan kemampuan biokontrol terhadap patogen tanaman dan nematoda (Toghueo, 2020).
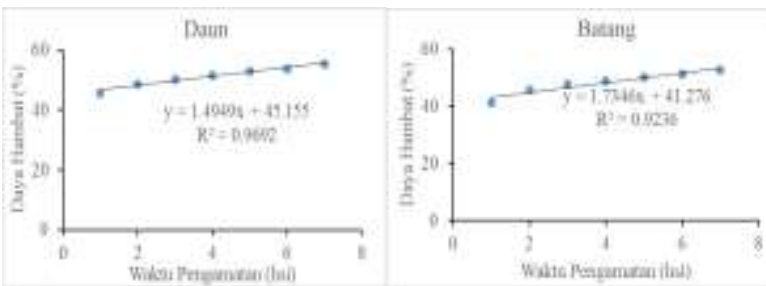

Gambar 3. Hubungan daya hambat cendawan endofit terhadap patogen Fusarium sp. pada berbagai waktu pengamatan.

Hubungan waktu pengamatan terhadap daya hambat pathogen Fusarium spp. Pada daun dan batang menunjukkan korelasi yang positif dengan nilai koefisien regresi sebesar 96,92\% dan $92,36 \%$. Hasil tersebut menunjukkan seiring dengan peningkatan waktu pengamatan maka cendawan endofit mampu menekan perkembangan patogen Fusarium sp. Berdasarkan hasil penelitian ini maka isolat bakteri endofit baik yang disiolasi pada daun maupun pada batang mampu menekan perkembangan patogen Fusarium sp.

Hasil penelitian menunjukkan bahwa cendawan endofit yang diisolasi dari batang dan daun tumbuhan rambusa mampu menekan perkembangan patogen Fusarium sp. Hal ini sejalan dengan penelitian sebelumnya yang melaporkan bahwa cendawan endofit mampu menekan perkembangan patogen (Nuraini et al., 2017; Suswanto et al., 2018; Ortiz-Ojeda et al., 2020). Suniti dan Sudarma (2016) melaporkan bahwa cendawan endofit yang diisolasi pada batang dan daun memiliki kemampuan prevalensi tertinggi dengan daya hambat sebesar hingga sebesar 73,37-100\%. Lebih lanjut dilaporkan, cendawan endofit mampu menghambat pertumbuhan $R$. solani tertinggi yang diisolasi dari $H$. capitata sebesar $58,99 \%$, Cladosporium sp. yang diisolasi dari jeruk bali $(55,42 \%)$, Pestalotiopsis sp. yang diisolasi dari nanas $(53,85$ $\%$ ), dan $P$. lilacinus yang diisolasi dari beringin $(51,81 \%)$ (Suciatmih et al., 2011).

Penelitian isolasi cendawan endofit dari batang dan daun juga dilaporkan mampu menekan perkembangan patogen $F$. oxysporum fsp. cubense (Foc) dengan kecepatan pertumbuhan $0,70 \mathrm{~cm}$ hari $^{-1}$ dan daya hambat 66\%, Baru (BR1) kecepatan pertumbuhan 0,60 $\mathrm{cm}$ hari $^{-1}$ dan daya hambat $40 \%$ (Sari dan Setiawanto, 2015). Lebih lanjut dilaporkan bahwa cendawan endofit dari bunga bawang dayak sehat dan yang mempunyai kecepatan tumbuh tercepat serta kemampuan menekan patogen Fusarium spp. secara in vitro (Rizali et al., 2021).

Penelitian relevan juga dilaporkan bahwa pengujian daya hambat isolat cendawan endofit dari buah kakao mempunyai daya hambat dengan persentasi $>30 \%$. Isolat cendawan endofit yang mempunyai daya hambat tertinggi terhadap Phythoptora palmivora setelah 5 hari inokulasi yaitu pada isolat B124 yaitu sebesar 58,62\%., kemudian diikuti oleh isolat B132 sebesar 57,00\% (Liswarni et al., 2018). Lebih lanjut dilaporkan bahwa mikroba endofit memiliki kemampuan dalam menghambat pertumbuhan fungi patogen Rigidoporus microporus dan Fusarium oxysporum (Lestari et al., 2017).

Cendawan endofit mempunyai kemampuan dalam menekan perkembangan patogen diduga disebabkan persaingan sumber daya atau niutisi 
yang dibutuhkan patogen untuk berkembang (Sudantha dan Abadi, 2007; Essarioui et al., 2017; Huda et al., 2019). Kompetisi dan antibiosis cendawan endofit terbukti mampu menekan patogen $P$. oryzae secara in vitro (Sopialena et al., 2020).

Cendawan endofit memiliki kemampuan perlindungan dalam menghambat pertumbuhan fitopatogen terhadap tanaman inang dengan memproduksi metabolit sekunder asam 13-oxo9.11-octadecadienoic dan biosintesis beauvericin, yang merupakan salah satu mikotoksin $F$. oxysporum (Combès et al., 2012). Lebih lanjut dilaporkan bahwa metabolit sekunder cendawan endofit isolat CECL 28 dapat menghambat Fusarium sp. (Sukapiring et al., 2016).

\section{Kesimpulan}

Cendawam endofit yang diisolasi dari daun dan batang tumbuhan rambusa mampu berperan sebagai agens antagonis patogen Fusarium sp. Daya hambat cendawan endofit tertinggi terhadap layu Fusarium sp. diperoleh pada daun dengan daya hambat mencapai $55,27 \%$ bila dibandingkan dengan daya hambat cendawan endofit yang diisolasi dari batang dengan daya hambat sebesar $52,64 \%$. Namun kedua isolat cendawan endofit ini, berpotensi sebagai agens pengendali hayati.

\section{Daftar Pustaka}

Afriani, A., M. Heviyanti, dan F. S. Harahap. (2019). Efektivitas Gliocladium virens untuk mengendalikan penyakit Fusarium oxysporum F. sp. capsici pada tanaman cabai. Jurnal Pertanian Tropik, 6(3): 403411.

Amaria, W., T. Efi, \& H. Rita. (2013). Seleksi dan identifikasi jamur antagonis sebagai agens hayati jamur Rigidoporus microporus pada tanaman karet. Journal of Industrial and Beverage Crops, 4(1): 20-31. doi:http://dx.doi.org/10.21082/jtidp.v4n1.20 13.p.

Andrade-Linares D. R., P. Franken. (2013). Fungal endophytes in plant roots: taxonomy, colonization patterns, and functions. in: Aroca R. (eds) symbiotic endophytes. Soil Biology, Vol 37. Springer, Berlin, Heidelberg. https://doi.org/10.1007/978-3-642-393174_16.
Basri1, M. H., L. Zulkifli dan A. Syukur. (2021). Isolation of endophytic fungi from Vitex trifolia L. and antagonism test against Sclerotium rolfsii and pathogenic bacteria. Jurnal Biologi Tropis, 21(1): 72-80. DOI: http://dx.doi.org/10.29303/jbt.v21i1.2340.

Combe`s, A., I. Ndoye, C. Bance, J. Bruzaud, C. Djediat. (2012). Chemical communication between the endophytic fungus paraconiothyrium variabile and the phytopathogen Fusarium oxysporum. PLoS ONE, $\quad 7(10)$ : e47313. doi:10.1371/journal.pone.0047313.

de Lamo, F. J. and F. L. W. Takken. (2020). Biocontrol by Fusarium oxysporum using endophyte-mediated resistance. Front. Plant Sci. 11: 37. Doi: 10.3389/fpls.2020.00037.

Essarioui, A., N. LeBlanc, H. C. Kistler. (2017). Plant community richness mediates inhibitory interactions and resource competition between Streptomyces and Fusarium populaions in the rhizosphere. Microb Ecol., 74: 157-167. https://doi.org/10.1007/s00248-016-0907-5.

Fitriani, M. L., S. Wiyono and M. S. Sinaga. (2019). Potensi kolonisasi mikoriza arbuskular dan cendawan endofit untuk pengendalian layu fusarium pada bawang merah. Jurnal Fitopalogi Indonesia, 15(6): 228-238. DOI: 10.14692/jfi.15.6.228-238.

Huda, N., W. Imaningsih, S. S. Hakim. (2019). Uji antagonisme kapang endofit tanaman galam (Melaleuca cajuputi) terhadap Colletotrichum truncatum. Jurnal Mikologi Indonesia, 3(2): 59-74.

Izzatinnisa, U. Utami, dan A. Mujahidin. (2020). Uji antagonisme beberapa fungi endofit pada tanaman kentang terhadap Fusarium oxysporum secara in vitro. Jurnal Riset Biologi dan Aplikasinya, 2(1): 18-25.

Lestari, W. (2017). Isolasi dan Uji antifungal bakteri endofit dari akar tanaman karet (Hevea brasilliensis). Simbiosa, 6(1): 48-56.

Liswarni, Y., Nurbailis dan M. Busniah. (2018). Eksplorasi cendawan endofit dan potensinya untuk pengendalian Phytophthora palmivora penyebab penyakit busuk buah kakao. Pros Sem. Nas. Masy. Biodiv. Indon., 4(2): 231-235. DOI: 10.13057/psnmbi/m040223. 
Nuraini, F. R., R. Setyaningsih, and A. Susilowati. (2017). Screening and characterization of endophytic fungi as antagonistic agents toward Fusarium oxysporum on eggplant (Solanum melongena). Biodiversitas, 18(4): 13771384. DOI: 10.13057/biodiv/d180413.

Ortiz-Ojeda, C. P., S. L. de Andrade and R. E. L. Procópio. (2020). Antifungal activity of endophytic microorganisms isolated from Acmella ciliata (Asteraceae). Genetics and Molecular Research, 19 (2): gmr18570.

Rizali, A., Aziza, N. L., Sari N. dan Irsalina S. (2021). Potensi cendawan endofit dari bunga bawang dayak dalam menekan patogen Fusarium spp. Prosiding Seminar Nasional Lingkungan Lahan Basah, 6(1). eISSN: 2623-1980.

Rusae, A., B. Metboki dan B. Atini. (2018). Kemampuan antagonis cendawan endofit terhadap Rhizoctonia sp. penyebab penyakit busuk akar tanaman sorgum (Sorghum bicolor L.) secara in vitro. Jurnal Metamorfosa, V(2): 198-204. ISSN: 23025697.

Saleh, N. (2004). Strategi pengendalian penyakit tanaman kedelai. Bul. Palawija, 7(8): 51-60.

Sari, W. dan E. Setiawanto. (2015). Potensi cendawan rizosfer pisang sebagai agen hayati terhadap cendawan Fusarium oxysporum f.sp cubense penyebab penyakit layu pada pisang. Jurnal Agroscience, 5(2): 37-42.

Sopialena, Suyadi, D. Tantiana dan A. N. Fauzi. (2020). Efektivitas cendawan endofit sebagai pengendali penyakit blast pada tanaman padi (Oryza sativa). Jurnal Agrifor, 14(2): 355-366.

Sriwanti, R., B. P. W. Sukarno, L. Hakim, dan S. Anjani. (2015). Uji potensi cendawan endofit asal tanaman pala dan potensinya sebagai agen hayati cendawan patogen. Prosiding Seminar Nasional dan Konggres XXIII Perhimpunan Fitopalogi Indonesia. Bekasi 11-13 November 2015.

Suciatmih, Yuliar and D. Supriyati. (2011). Isolasi, identifikasi, dan skrining jamur endofit penghasil agen biokontrol dari tanaman di lahan pertanian dan hutan penunjang gunung salak. J. Tek. Ling., 12(2): 171-186. ISSN 1441-318X.
Sudantha, I. M. dan A. L. Abadi. (2007). Identifikasi jamur endofit dan mekanisme antagonismenya terhadap jamur Fusarium oxysporum f. sp. vanillae pada tanaman vanili. Agroteksos, 17(1): 23-38.

Sudewi, S., A. Ala, Baharuddin dan M. Farid. (2020). Keragaman organisme pengganggu tanaman (OPT) pada tanaman padi varietas unggul baru (vub) dan varietas lokal pada percobaan semi lapangan. Jurnal Agrikultura, 31(1): 15-24.

Sukapiring, D. N., B. P. W. Soekarno dan T. S. Yuliani. (2016). Potensi metabolit sekunder cendawan endofit tanaman cabai sebagai penghambat Fusarium sp. patogen asal biji secara in vitro. Jurnal Fitopalogi Indonesia, 12(1): 1-8. DOI: 10.14692/jfi.12.1.1.

Suniti, N. W. dan I. M. Sudarma. (2016). Uji daya hambat jamur endofit dan eksofit dalam menekan pertumbuhan Fusarium oxysporum f.sp. vanillae penyebab busuk batang panili secara in vitro. Agrotrop, 6(2): 137-145.

Susanti, A., N. Afifah \& R. Febrianti. (2021). Penekanan jamur endofit terhadap patogen pada tanaman jambu bol gondang manis. Journal Viabel Pertanian, 15(1): 1-15.

Suswanto, I., C. J. K. Simamora dan D. Anggorowati. (2018). Penggunaan cendawan endofit sebagai agens pengendali hayati pada lada (Piper nigrum L.). Jurnal Agroqua, 16(2): 143-151.

Suwardani, N. W., Purnomowati, E. T. Sucianto. (2014). Kajian penyakit yang disebabkan oleh cendawan pada tanaman cabai merah (Capsicum annum L.) di pertanaman rakyat Kabupaten Brebes. Scripta Biologica, 1(3): 223-226.

HTTPS://DOI.ORG/10.20884/1.SB.2014.1. 3.554 .

Toghueo, R. M. K. (2020). Bioprospecting endophytic fungi from fusarium genus as sources of bioactive metabolites. Mycology, 11(1): $\quad 1-21$. https://doi.org/10.1080/21501203.2019.164 5053.

Tumangger, B. S., N. Baiduri, F. Nadila, Fitriani dan V. Mardina. (2018). Uji potensi cendawan endofit asal mangrove sebagai bioprotektan terhadap patogen Fusarium sp. pada tanaman padi hitam (Oryza sativa 
Jurnal Agratech 11 (2) 64-70, Desember 2021

L "Cempo Ireng") secara in vitro. Jurnal Jeumpa, 5(1): 45-49.

Wahyuni, S. dan N. Noviani. (2019). Isolasi jamur endofit dan uji penghambatan dengan jamur patogen Fusarium oxysporum sebagai agen pengendali hayati pada tanaman kedelai secara invitro. Prosiding Seminar Nasional \& Exspo Hasil Penelitian dan Pengabdian Masyarakat, 2019: 712-719.
e-ISSN : 2621-7236

p-ISSN : 1858-134X

Wei, F., Y. Zhang, Y. Shi, H. Feng, L. Zhao, Z. Feng and H. Zhu. (2019). Evaluation of the biocontrol potential of endophytic fungus Fusarium solani CEF559 against Verticillium dahliae in Cotton Plant. Hindawi BioMed Research International, Volume 2019, Article ID 3187943, 12 p. https://doi.org/10.1155/2019/3187943. 